\title{
MIR29C Gene
}

National Cancer Institute

\section{Source}

National Cancer Institute. MIR29C Gene. NCI Thesaurus. Code C80722.

This gene is involved in the regulation of gene expression and plays a role in the development of carcinomas of the lung and nasopharynx as well as rhabdomyosarcoma and type II diabetes. 